\title{
The influence of private school enrollment on public school performance
}

\author{
Michael L. Marlow \\ Department of Economics, California Polytechnic State University, \\ San Luis Obispo, CA 93407 \\ E-mail:mmarlow@calpol.edu
}

\begin{abstract}
School choice reform refers to changes that allow parents greater freedom to choose schools for their children. School choice reform is contentious because it fundamentally alters the environment in which public and private schools operate and could result in significant changes for both demanders and suppliers of education. This article develops a model of public education with imperfect exit to predict how private school enrollment influences performance of public schools. Empirical evidence from data on all private and public schools in California provides substantial support for the hypothesis that public school test scores are inversely related to private school enrollments and charter school enrollments when private and charter schooling reflects exiting by parents unhappy with local public schools. Implications regarding how expanded private school choice might influence public school performance in California and elsewhere are discussed.
\end{abstract}

\section{Introduction}

Proposals calling for school choice reform are often attributed to Milton Friedman's (1955) advocacy of tuition vouchers as a means of improving public and private schools. School choice reform refers to changes that allow parents greater freedom to choose schools for their children. For example, vouchers or tax-preferences that subsidize tuition, books and transportation costs expand private school choice because they lower costs associated with private schooling. Easing of restrictions that base public school admission on housing location expands public school choice by widening numbers of public schools to choose from. It is not surprising that school choice reform is contentious because it fundamentally alters the environment in which public and private schools operate and could result in significant changes for both demanders and suppliers of (public and private) education.

Opponents of expanded choice often fear that poorlyperforming public schools will lose quality students as parents exercise greater opportunities to transfer to other public schools or choose private schools. Such sorting is often termed 'cream-skimming' by opponents who predict that it lowers peer group quality and public funding for public schools losing students and fear that gaps between poor-quality and high-quality schools could widen. Proponents argue that public schools should worry about greater school choice only when schools are perceived to be inferior to other public 
or private schools. Poor performance is considered likely according to proponents because lack of exit opportunities subjects public schools to little competition and therefore expanded opportunities for exit should create incentives for poor quality schools to improve or keep losing students and funding. As performance improves, performance gaps between schools might shrink.

This article addresses the debate over expanded school choice by examining how private enrollments influence performance of public schools. Private schooling is clearly one option for parents unhappy with public schools and therefore private enrollments may inversely influence public school performance as long as private schools outperform public schools. This article examines data on all private and public schools in California in 2003 and concludes that, after controlling for other factors that might influence performance, public school performance is inversely related to private school enrollments. Implications regarding how expanded private school choice might influence future public school performance in California and elsewhere are discussed.

\section{Public Education with Imperfect Exit}

Public education programmes result from exchange between voters-demanders and policymakers-suppliers and, as in private markets, exchanges may take place under different market structures. Public education markets may be competitive or monopolistic as influenced by the degree to which voterdemanders have exit options over public programs they receive. Voters-demanders include parents, homeowners, and employers who all view quality education in one way or another linked to their interests. When parents conclude that local public schools are unable to deliver programs they desire, they may exit to preferred education programs along the lines outlined by Tiebout's (1956) model of 'voting-with-your-feet'. Exiting behaviour may include transfers to other public schools, home schools or private schools. The Tiebout model predicts that citizens with similar interests tend to assemble in similar political jurisdiction which suggests that local residents will exhibit fairly uniform preferences for programmes such as public education. ${ }^{1}$ Under certain conditions, Tiebout-type mobility within a system of many exit opportunities leads to a Pareto-efficient equilibrium. ${ }^{2}$

Ability-to-exit a particular public school, however, is clearly imperfect and influenced by ease of transfer to other public schools and affordability and availability of local private schools. Parents are often assigned specific schools within their school districts and such 'exclusive territories' force parents to undertake costly relocation if they want different public schools, even though moves may be short distances. ${ }^{3}$ Tuition at private schools may also be prohibitive thus also lowering exit ability of some parents. Few exit options enable public schools to exhibit some degree of monopoly power.

Financing public education through the ability-topay principle may also contribute to lower school performance as parents with public school children may be less interested in monitoring quality than they would under the benefit principle of taxation. Tax bills of parents are not sensitive to numbers of schoolage children and probably lead to less concern over quality than would arise if tax bills rose with consumption. That is, taxpayers with school-age children do not face higher tax bills, at the margin, for sending children to public or private schools than taxpayers without school-age children. Moreover, because parents do not have abilities to quit paying for public education if they exit to private education, this financing system likely promotes less scrutiny of public school performance than would arise if they did not 'pay twice' for education when exiting to private schools. In contrast, parents purchasing private education face tuition bills directly related to numbers of children sent and therefore incentives arise for these parents to carefully monitor performance because they have the ability to exit and no longer fund private education.

This discussion suggests that private schools have greater incentives to provide superior performance over public schools because parents have choices about whether they will choose private schooling and pay tuition. Parents therefore have great financial incentives to monitor performance very closely when they choose to fund private schools. Average tuition in 1999 ranged from $\$ 3263$ for Catholic schools to $\$ 19992$ for secular schools, with $\$ 4689$ being the

\footnotetext{
${ }^{1}$ Martinez-Vazquez and Seaman (1985) and Hamilton and Macauley (1991) find that, when communities with diverse populations have relatively few school districts, there are more private schools. Evidence then suggests that private enrollments are higher when public schools do not support diverse preferences and so greater numbers of private schools provide more exit opportunities for demanders.

${ }^{2}$ Assumptions include perfect information and mobility and absence of free riders and interjursidictional externalities.

${ }^{3}$ See West (1990) for a discussion. There may also be some ability to petition to attend another public school.
} 
average for all private schools. ${ }^{4}$ Evidence indicates that private schools consistently achieve higher rates of attendance and graduation, levels of parental satisfaction and college admission rates than public schools. ${ }^{5}$ However, added expense of tuition clearly places private schools at a price disadvantage that contributes to the fact that private schooling commands only about $10 \%$ of primary and secondary education in the United States. Proponents of expanded school choice predict that greater exit opportunities would lead to greater threats of exodus out of public education if public schools fail to respond to heightened competitive pressures by improving performance.

The National Education Association (NEA), which is the largest teachers' organization with 2.7 million members, holds an opposing view. This view focuses on improving public education by raising salaries, numbers of teachers and other conventional inputs in the production of education. NEA's opposition to expanded school choice is clear:

Teachers, parents, and the general public have long opposed private school tuition vouchers - especially when funds for vouchers compete with funds for overall improvements in America's public schools. NEA and its affiliates have been leaders in the fight to improve public schools - and oppose alternatives that divert attention, energy, and resources from efforts to reduce class size, enhance teacher quality, and provide every student with books, computers, and safe and orderly schools. ${ }^{6}$

NEA appears to equate quality with inputs and predicts that expanded school choice lowers public education quality whenever it leads to less public funding. While this view is consistent with the Tiebout-model prediction that expanded private school choice raises flight to private schools, apparently 'voting-with-your-feet' is not considered a viable method for improvement due to fears of funding reduction and/or that exiting will be undertaken mostly by higher-aptitude students or higherincome families. ${ }^{7}$

This discussion leads to the hypothesis that when private schooling reflects exiting by parents unhappy with local public schools, relatively high private enrollments reflect greater dissatisfaction with local public schools. Public school performance should then be inversely related to private enrollments based on the view that parents choosing private education are sensitive to public school quality as reflected in such measures as test scores. Empirical evidence that private enrollments are inversely related to public school performance then indicates that public schools lose quality students to private schools under the assumption that parents choosing private education are more interested in higher quality education. Of course, there are many possible factors that might explain why parents perceive private education to be worth tuition payments and include better peer groups, more interested parents, and/or greater incentives to produce higher quality product following our previous discussion on why private schools may out-perform public schools.

According to proponents of expanded school choice, this negative relationship may eventually disappear if public schools respond by raising performance to levels that counter exodus of better students. In this case, no relation between private enrollments and public school performance should appear. Otherwise, a negative relation is consistent with the view that private schools provide performance that is sufficiently above public schools to lead to relatively high private enrollments. Stated differently, public schools are expected to exhibit higher test scores in communities with relatively low private enrollments because such communities have relatively little demand for private schools because their public schools offer relatively high performance.

\footnotetext{
${ }^{4}$ See National Center for Education Statistics (2002).

${ }^{5}$ See, for example, Alt and Peter (2003). However, it should be noted, that Coleman et al. (1966), or the so-called Coleman Report, concluded that the strongest predictor of student performance was family background as, for example, measured by household income and parental socio-economic status. Therefore, conventional measures such as per pupil spending and student-to-teacher ratios were found to be relatively unimportant in most cases. This report prompted numerous studies that mostly supported the original findings of the Coleman Report as discussed in Hanushek's (1986) extensive survey of the literature. More recently, others have argued that school effects such as per pupil funding are more important than previously believed. See, for example, Card and Krueger (1992) and Hedges et al. (1994). Several researchers doubt the validity of recent studies concluding that school effects are important; see, for example, Betts (1995), Grogger (1996) and Hanushek et al. (1996). While debate continues on how important school effects are, most researchers appear to agree that nonschool effects such as family and community background are quite important when it comes to determining student performance. Therefore, perhaps school effects are less important as well than nonschool effects in explaining student performance differences between private and public schools."

${ }^{6}$ Quote taken off http://www.nea.org/vouchers/index.html during December 2005.

${ }^{7}$ The following quote from NEA's website http://www.nea.org/vouchers/index.html during December 2005 makes it clear that they view vouchers as a threat to poorly-performing public schools: 'NEA and its affiliates support direct efforts to improve public schools. There is no need to set up new threats to schools for not performing. What is needed is help for the students, teachers, and schools who are struggling.'
} 


\section{School Choice in California}

California provides a large data set to examine how private enrollments are related to public school performance. California enrolls roughly $13 \%$ of all public primary and secondary students in the nation. ${ }^{8}$ There are more than 6 million public school students (primary and secondary education) served by about 9000 public schools in over 1000 public school districts. There are roughly 600000 private school students served by 3700 private schools. The private share of all education in California then is roughly $9 \%$ and is consistent with the national average. ${ }^{9}$

California Department of Education publishes data on many aspects of private schools. ${ }^{10}$ All private schools serving elementary or high school students, and who enroll at least six students, are required to file an affidavit or statement each year with the State Superintendent of Public Instruction. A summary of selected information for the 2003-2004 school year follows. Students in private schools accounted for 9\% of 2003-2004 enrollments in all public and private schools. Of the 599605 private school students, 450274 were enrolled in elementary grades (K-8) and 149331 were enrolled in secondary grades $(9-12)$. Sixtyfour percent of students enrolled in private schools attended church-affiliated (religious) schools, with Roman Catholic schools accounting for $39 \%$ of the total number of church-affiliated schools and serving $59 \%$ of students attending such schools.

The data exhibit wide variation in shares of students in private school enrollments and between counties thus indicating substantial range of private school choice. ${ }^{11}$ The average (median) share of students enrolled in private schools as a percentage of all enrollments is $6.2 \%(5.1 \%)$, with a range of $0-29.1 \%$. The average (median) share of students enrolled in religious schools as a percentage of all enrollments is $5.0 \%(4.4 \%)$, with a range of $0-22 \%$. The average (median) share of students enrolled in Catholic schools as a percentage of all enrollments is $2.1 \%(1.4 \%)$, with a range of $0-17 \%$. Finally, the average (median) share of students enrolled in secular schools as a percentage of all enrollments is $1.1 \%(0.4 \%)$, with a range of $0-8.8 \%$. Data indicate that a majority of private school enrollments are in religious schools, with roughly $40 \%$ of those enrollments in Catholic schools.

Two propositions that would have allowed vouchers in California were defeated in recent years. ${ }^{12}$ Proposition 174 in 1993 would have amended the state constitution to provide vouchers for families to enroll their children in public, private or parochial schools. In 2000, Proposition 38, a voter initiative to provide parents, regardless of income, with universal vouchers worth $\$ 4000$ per child for use at any public or private school, was also defeated.

Private and public school choices may also be expanded through tax preferences. The federal government offers education savings accounts such as the Coverdell Educations Savings Accounts that enable parents to save up to $\$ 2000$ annually in bank accounts that are free from taxation and to apply this money to K-16 educational expenses. Various states allow tax credits and deductions for certain educational expenses such as private school tuition, books and transportation, but California does not offer similar tax-preferences.

While California does not directly subsidize private school choice through vouchers or taxpreferences, recent developments have expanded public school choice. In 1992, the Charter School Act was passed (amended in 1998, 1999, 2002 and 2003) and currently permits establishment of 650 charter schools and raises the cap by 100 schools for each subsequent academic year. Local school boards, county boards of education and the California State Board of Education may authorize charters and these schools receive $100 \%$ of public schools' per-pupil funding. Teachers in charter schools are required to be certified. In 2003, there were 154365 students enrolled in 443 charter schools.

Two California bills passed in 1993 - 4 Assembly Bill 1114 and A.B. 19 - give parents rights to transfer children to other public schools within and outside their district, subject to space limitations or

\footnotetext{
${ }^{8}$ Data from Statistical Abstract of the United States, 2003.

${ }^{9}$ In 1999-2000, approximately 27000 private schools, with 404000 full-time-equivalent (FTE) teachers, enrolled 5.3 million students. These schools accounted for $24 \%$ of all schools in the United States, $10 \%$ of all students, and $12 \%$ of all FTE teachers; see US Department of Education (2002).

${ }^{10}$ Numbers discussed here are from California Department of Education (2004).

${ }^{11}$ Counties having $10 \%$ or more of their total students enrolled in private schools in 2003-2004 were: Alameda (11.8\%), Contra Costa (10.3\%), Los Angeles (10.5\%), Marin (18.7\%), Napa (13.4\%), Orange (10.1\%), San Francisco (29.1\%), San Mateo (15.4\%), Santa Clara (12.4\%) and Santa Cruz (11.2\%).

${ }^{12}$ These defeats are consistent with Kenny's (2005) discussion of initiatives that concludes that voucher bills have been passed only in the more conservative Republican states.
} 
racial balance policies. Successful transfer may have previously required residential relocation. These mandatory intradistrict choice laws enable parents to choose from schools within their district of residence. Interdistrict transfers are limited to districts that elect to participate. Unfortunately, it is unclear how California fits into national trends because the California Department of Education does not report how many parents elect public school choice. But, the US Department of Education (2003) reports that $14 \%$ of students attended a public school of choice in 1999 and the trend away from public, assigned school enrollment and toward public, chosen school enrollment between 1993 and 1999 was most evident in lowincome households. Under the 2002 federal No Child Left Behind Act, children attending schools that have failed to make adequate yearly progress toward meeting state standards for two consecutive years are eligible to transfer to better-performing schools within their district.

In sum, California does not facilitate private school choice through vouchers or tax-preferences, but public school choice is fostered to the extent that parents can take advantage of mandatory intradistrict and voluntary interdistrict transfers laws. It remains unclear how easy it is for parents to exercise public school choice because enrollments are dependent upon space limitation and racial balance policies and no data are reported on these transfers. This is unfortunate because private enrollments are likely to be related to both ease of intradistrict and interdistrict transfer and to perceived quality gaps between high- and low-performing schools. Data on location and frequency by which transfers occur might reveal much about parental preferences regarding public school choice as well as how it influences private enrollments.

Ease of public school choice should be related to numbers of school districts within counties because choice should rise with numbers of school districts when local policies affecting school quality are made at the level of school districts. The Herfindahl index, or the sum of squared shares of school district enrollments within counties, then measures ease of transfer from one district to another and controls for influences of public school choice on private enrollments. Greater public transfer options, as measured by Herfindahl scores, is hypothesized to lower private enrollments when greater public school choice lessens need for parents to exit public schools for private schools.

\section{Modelling Effects of Private Enrollments on Public School Performance}

Endogeneity is an issue of concern if the causal relationship between public school performance and private school enrollment is two-way. One possible direction is that public school performance causes private school enrollment as, for instance, high-test scores in public schools cause private enrollments to be relatively low. But, private school enrollment could also cause public school performance when, for instance, better students exit to private schools thus causing public school scores to fall. Disentanglement of these causal effects is a critical issue when we examine influences of private enrollments on public school performance. Possibility of two-way causality is addressed here by using two-stage least squares to estimate models of public school performance. Ordinary least squares produces biased and inconsistent estimates of coefficients in presence of simultaneity. Also, to control for possibility of differential variance by county size, equations are estimated with SEs and variances that use White's (1980) covariance estimator. Estimates of coefficient covariances are calculated in presence of heteroskedasticity of unknown form.

The model of public school performance in (1) is estimated by two-stage least squares, where 57 counties in 2003 are the unit of observation. All California counties are included except Alpine which is excluded because of missing data. ${ }^{13}$ Cross-county estimation is appropriate because school districts are organized within counties in California and overseen by county boards of education, all of which are elected except for Los Angeles County's board which is appointed by its Board of Supervisors.

SCORE $_{i}=f\left(\right.$ INCOME $_{i}, \quad$ DENSITY $_{i}, \quad$ TAKE $_{i}$,
SPEND $_{i}, \quad$ HERF $_{i}, \quad$ PRIVATE $_{i}, \quad$ LEARNERS $_{i}$,
CHARTERS $\left._{i}\right)(1)$

The first-stage equation is

PRIVATE $_{i}=f\left(\mathrm{INCOME}_{i}, \quad\right.$ DENSITY $_{i}, \quad$ TAKE $_{i}$, $\mathrm{SPEND}_{i}, \quad \mathrm{HERF}_{i}, \quad \mathrm{HISP}_{i}, \quad \mathrm{ASIAN}_{i}, \mathrm{BLACK}_{i}$, LEARNERS $_{i}$, CHARTERS $_{i}$ ) (2)

Variables are defined along with summary statistics in Table 1. Data were collected from the California Department of Education website to measure and calculate all education-related variables. Income $\left(\mathrm{INCOME}_{i}\right)$, and population density $\left(\mathrm{DENSITY}_{i}\right)$

\footnotetext{
${ }^{13}$ Alpine County had a total public school enrollment of only 148 in 2003.
} 


\begin{tabular}{|c|c|c|c|c|}
\hline & Mean & Median & $\mathrm{SD}$ & Range \\
\hline MSAT $=$ math SAT score & 515.5 & 517.0 & 29.4 & $454-571$ \\
\hline VSAT $=$ verbal SAT score & 502.8 & 5.08 .0 & 29.1 & $449-567$ \\
\hline $\mathrm{TSAT}=$ math + verbal SAT scores & 1018.4 & 1022.0 & 56.9 & $903-1138$ \\
\hline INCOME $=$ per capita personal income & 29456 & 25781 & 9481.4 & $18893-65642$ \\
\hline DENSITY $=$ population per square mile & 375.4 & 99.3 & 720.5 & $1.8-3393.3$ \\
\hline $\mathrm{TAKE}=\%$ of 12 th graders taking SAT tests & 30.5 & 30.4 & 9.7 & $14.4-59.1$ \\
\hline SPEND $=$ expenditures per public school student & 7307 & 6935 & 875 & $5927-10216$ \\
\hline CATHOLIC $=\%$ of students in Catholic schools & 2.1 & 1.4 & 2.7 & $0.0-17.0$ \\
\hline RELIGIOUS $=\%$ of students in religious schools & 5.0 & 4.4 & 3.5 & $0-22.0$ \\
\hline SECULAR $=\%$ of students in secular schools & 1.1 & 0.4 & 1.7 & $0-8.8$ \\
\hline PRIVATE $=\%$ of students in private schools & 6.2 & 5.1 & 4.9 & $0-29.1$ \\
\hline HERF $=$ Herfindahl index of public schools & 2931 & 1788 & 2828 & $567-10000$ \\
\hline $\mathrm{HISP}=$ share of public school students of Hispanic origin & 0.3 & 0.3 & 0.2 & $0-0.85$ \\
\hline ASIAN $=$ share of public school students of Asian origin & 0.05 & 0.02 & 0.07 & $0-0.4$ \\
\hline BLACK = share of public school students that are African-American & 0.04 & 0.02 & 0.05 & $0-0.20$ \\
\hline CHARTERS $=$ share of students in charter schools & 3.92 & 1.97 & 5.52 & $0-21.2$ \\
\hline
\end{tabular}

variables were collected from the California Statistical Abstract, 2004.

The dependent variable in (1) is $\mathrm{SCORE}_{i}$ and refers to two public school test scores: SAT verbal and SAT math scores. Higher values indicate higher performance and these measures are consistent with those used in other studies. ${ }^{14}$ Maximum scores of separate verbal and math SATs are 800 .

$\mathrm{INCOME}_{i}$ controls for influence of income on test scores based on the hypothesis that higher incomes raise demand for quality in public education. This hypothesized effect is consistent with the view that parents prefer quality education. Also public school quality is a critical component of local property values and, because income is probably highly correlated with property values, income is hypothesized to exert a positive influence. It is common to include education attainment in the community as another factor influencing school performance, but it is not included here because of high correlation with income. $^{15}$

DENSITY $_{i}$ measures population density as defined by population divided by square miles and controls for differences that might arise between urban and rural counties. It is often argued that urban schools experience greater scale economies than rural schools thus allowing for greater performance from a given budget. However, urban schools may also suffer many social ills often associated with inner cities thus suggesting that greater density may exert an inverse influence as well. The net effect of these influences is an empirical issue.

Percentage of 12th grade students taking SAT exams $\left(\mathrm{TAKE}_{i}\right)$ controls for the expectation that higher values result in lower test scores because higher percentages indicate, at the margin, lower aptitude students are taking tests. Larger percentages therefore are hypothesized to indicate that more lower-aptitude students take tests thus exerting downward pressure on average test scores.

Public school spending SPEND $i$ controls for effects on test scores that arise from differences in spending across counties. Spending is measured as spending per student in 'average daily attendance.' While conventional wisdom appears to be that higher spending leads to higher performance, the oftencited review of the literature by Hanushek (1986) suggests that this relationship is weak at best.

The Herfindahl score HERF $F_{i}$ is expected to exert a negative effect on test scores based on the hypothesis that fewer public school choice options should negatively influence public school performance. As discussed, larger Herfindahl scores indicate fewer inter-district transfer options thus indicating fewer exit options, or simply less public school choice. Borland and Howsen (1992), Blair and Staley (1995), Zanzig (1997) and Marlow (2000) find that Herfindahl indices exert competitive pressures on public school performance. The Herfindahl index is the sum of squared shares in each market and

\footnotetext{
${ }^{14}$ For instance, see the review of more than 35 studies assessing public school performance in Belfield and Levin (2001). Also, Lankford and Wyckoff (1992) find that parents are sensitive to school quality as measured by test scores of public and private elementary schools.

${ }^{15}$ Educational attainment is measured by the percentage of adults over the age of 25 with at least a bachelor's degree in 2000 and is published in the Statistical Abstract of the United States, 2003. Results did not change when educational attainment was substituted for income.
} 
Table 2. 2SLS Estimates of catholic enrollments on public school performance estimated coefficients ( $t$-statistics in parentheses)

\begin{tabular}{|c|c|c|c|}
\hline \multirow[b]{2}{*}{ Dependent variable } & \multirow{2}{*}{$\frac{\text { Cath03 }}{\text { 1st Stage }}$} & \multirow{2}{*}{$\frac{\text { Math03 }}{\text { 2nd Stage }}$} & \multirow{2}{*}{$\frac{\text { Verbal03 }}{\text { 2nd Stage }}$} \\
\hline & & & \\
\hline \multirow[t]{2}{*}{ INCOME } & $0.0002 *$ & $0.003 *$ & $0.004 *$ \\
\hline & 5.79 & 3.28 & 4.38 \\
\hline \multirow[t]{2}{*}{ DENSITY } & 0.0003 & $0.013 * *$ & $0.011^{* *}$ \\
\hline & 0.56 & 2.56 & 1.90 \\
\hline \multirow[t]{2}{*}{ TAKE } & $-0.069 * *$ & -1.010 & -1.126 \\
\hline & 2.06 & 1.38 & 1.29 \\
\hline \multirow[t]{2}{*}{ SPEND } & $0.0003 * * *$ & 0.002 & 0.007 \\
\hline & 1.84 & 0.29 & 1.29 \\
\hline \multirow[t]{2}{*}{ CATHOLIC } & & $-4.230 * * *$ & $-10.673^{*}$ \\
\hline & & 1.81 & 3.43 \\
\hline \multirow[t]{2}{*}{ HERF } & 0.0001 & -0.0004 & -0.001 \\
\hline & 1.38 & 0.36 & 0.05 \\
\hline \multirow[t]{2}{*}{ HISPANIC } & 2.821 & & \\
\hline & 0.97 & & \\
\hline \multirow{2}{*}{ ASIAN } & $15.805 * * *$ & & \\
\hline & 1.98 & & \\
\hline \multirow[t]{2}{*}{ AFRICAN } & 6.957 & & \\
\hline & 1.33 & & \\
\hline \multirow[t]{2}{*}{ CHARTERS } & $-0.057 * *$ & $-1.254 * *$ & $-1.293 * *$ \\
\hline & 2.10 & 2.21 & 2.07 \\
\hline \multirow[t]{2}{*}{ LEARNERS } & 0.845 & $-127.794 *$ & $-110.152 *$ \\
\hline & 0.16 & 4.89 & 4.41 \\
\hline \multirow[t]{2}{*}{ CONSTANT } & $-6.038^{*}$ & $476.224 *$ & $487.14^{*}$ \\
\hline & 2.90 & 12.35 & 4.76 \\
\hline$R^{2}$ & 0.76 & & \\
\hline$N$ & 57 & 57 & 57 \\
\hline$F$ & 19.14 & & \\
\hline MEAN DEP. VARIABLE & 2.09 & 515.53 & 502.84 \\
\hline
\end{tabular}

Note: $* * *$ and $* * *$ significant (two-tailed test) at 1,5 and $10 \%$ levels, respectively

therefore has a minimum value of near 0 and a maximum value of 10000 . Lower values indicate competitive markets and, at the extreme value of 10000 , a perfect monopoly district that controls all public education in that county.

PRIVATE $_{i}$ measures private school enrollments as percentages of all (private and public) students in each county. Previous discussion hypothesized that greater private school choice leads to lower public school test scores when public schools are considered inferior to private schools. Four measures of private school choice are examined: enrollments at Catholic, religious, secular and all or combined schools. It is possible that religious school enrollments, and especially those of Catholic schools, exert competitive pressures on public schools that differ from those from secular schools. Religious enrollments tend to offer subsidized tuition to a large segment of students as well as religious instruction that may not directly raise performance on standardized tests. Secular schools generally charge higher tuition and are 'college-prep' in nature and so may cater more to higher-aptitude students than do religious schools. Each of three private school enrollments are considered separately and then combined to examine whether each exerts different influences on public school test scores.

CHARTERS $_{i}$ is defined as the share of all county students attending charter schools in 2003 and is calculated from data on the California Education Department's website. Charters schools provide parents with another means of avoiding more traditional public schools and therefore it is hypothesized that a negative sign would indicate greater charter school choice leads to lower public school test scores when traditional public schools are considered inferior to private schools.

Percentage of all students that are classified as English-learners LEARNERS $_{\mathrm{i}}$ is hypothesized to exert a negative influence on test scores based on the conventional view that their lack of fluency places them at a disadvantage. 
Table 3. 2SLS estimates of religious enrollments on public school performance estimated coefficients ( $t$-statistics in parentheses)

\begin{tabular}{|c|c|c|c|}
\hline & Relig03 & Math03 & Verbal03 \\
\hline $\begin{array}{l}\text { Dependent } \\
\text { variable }\end{array}$ & 1st Stage & 2nd Stage & 2nd Stage \\
\hline \multirow[t]{2}{*}{ INCOME } & $0.0003^{*}$ & $0.004 *$ & $0.006^{* *}$ \\
\hline & 5.08 & 2.69 & 2.50 \\
\hline \multirow[t]{2}{*}{ DENSITY } & $0.001 * * *$ & $0.022 * *$ & $0.024 * * *$ \\
\hline & 1.77 & 2.67 & 1.78 \\
\hline \multirow[t]{2}{*}{ TAKE } & $-0.125^{* *}$ & -1.619 & -2.123 \\
\hline & 2.31 & 1.43 & 1.47 \\
\hline \multirow[t]{2}{*}{ SPEND } & -0002 & -0.003 & -0.002 \\
\hline & 0.81 & 0.39 & 0.24 \\
\hline \multirow[t]{2}{*}{ RELIG } & & $-7.805 * * *$ & $-14.765^{* *}$ \\
\hline & & 1.85 & 2.13 \\
\hline \multirow[t]{2}{*}{ HERF } & 0.0002 & 0.0001 & 0.001 \\
\hline & 1.43 & 0.30 & 0.53 \\
\hline \multirow{2}{*}{ HISPANIC } & 2.449 & & \\
\hline & 0.58 & & \\
\hline \multirow[t]{2}{*}{ ASIAN } & 10.354 & & \\
\hline & 1.27 & & \\
\hline \multirow[t]{2}{*}{ AFRICAN } & $9.039 * * *$ & & \\
\hline & 1.64 & & \\
\hline \multirow[t]{2}{*}{ CHARTERS } & & 0.008 & -0.551 \\
\hline & & 0.21 & 0.60 \\
\hline \multirow[t]{2}{*}{ LEARNERS } & -0.922 & $-122.889^{*}$ & $-112.594 * * *$ \\
\hline & 0.11 & 2.86 & 1.84 \\
\hline \multirow[t]{2}{*}{ CONSTANT } & -0.716 & $504.429 *$ & $478.965^{*}$ \\
\hline & 0.24 & 11.74 & 9.05 \\
\hline$R^{2}$ & 0.75 & & \\
\hline$N$ & 57 & 57 & 57 \\
\hline $7 F$ & 17.59 & & \\
\hline MEAN DEP. & 5.04 & 515.53 & 502.84 \\
\hline VARIABLE & & & \\
\hline
\end{tabular}

Note: *,** and *** significant (two-tailed test) at 1, 5 and $10 \%$ levels, respectively

Instruments for first-stage estimation in (2) are all independent variables in (1) except PRIVATE $_{i}$ and the addition of $\mathrm{HISP}_{i}$ (share of public school population of Hispanic origin), $\operatorname{ASIAN}_{i}$ (share of public school population of Asian origin) and BLACK $_{i}$ (share of public school population of African-American origin). Previous studies have shown that private school enrollments are higher in areas of higher income and those with stronger religious preferences. ${ }^{16}$ Downes and Greenstein (1996) examine location choice of California private schools in 1978-1979 and conclude that locational choice is influenced by local demographics and ethnicity. Shares of public school populations that are of Hispanic, Asian and African-American origin are included to control for ethnic composition.
Table 4. 2SLS estimates of secular enrollments on public school performance estimated coefficients ( $t$-statistics in parentheses)

\begin{tabular}{|c|c|c|c|}
\hline & $\mathrm{Sec} 03$ & Math03 & Verbal03 \\
\hline $\begin{array}{l}\text { Dependent } \\
\text { Variable }\end{array}$ & 1st Stage & 2nd Stage & 2nd Stage \\
\hline INCOME & $\begin{array}{l}0.0002 * \\
5.21\end{array}$ & $\begin{array}{l}0.004 * * \\
2.15\end{array}$ & $\begin{array}{l}0.006 * * \\
3.01\end{array}$ \\
\hline DENSITY & $\begin{array}{c}-0.001 \\
0.45\end{array}$ & $\begin{array}{l}0.009^{* *} \\
2.43\end{array}$ & $\begin{array}{l}0.001 \\
0.18\end{array}$ \\
\hline TAKE & $\begin{array}{c}-0.033 \\
1.58\end{array}$ & $\begin{array}{c}-1.075 \\
1.21\end{array}$ & $\begin{array}{c}-1.331 \\
1.55\end{array}$ \\
\hline SPEND & $\begin{array}{l}0.0004 * * \\
2.37\end{array}$ & $\begin{array}{l}0.004 \\
0.64\end{array}$ & $\begin{array}{l}0.013 * * \\
2.22\end{array}$ \\
\hline SEC & & $\begin{array}{c}-10.307 \\
1.10\end{array}$ & $\begin{array}{c}-27.448 * * \\
2.43\end{array}$ \\
\hline HERF & $\begin{array}{c}-0.0002 \\
0.44\end{array}$ & $\begin{array}{c}-0.001 \\
1.10\end{array}$ & $\begin{array}{c}-0.002 \\
1.47\end{array}$ \\
\hline HISPANIC & $\begin{array}{l}2.546 \\
1.38\end{array}$ & & \\
\hline ASIAN & $\begin{array}{l}6.285^{* *} \\
2.04\end{array}$ & & \\
\hline AFRICAN & $\begin{array}{l}0.600 \\
0.21\end{array}$ & & \\
\hline CHARTERS & $\begin{array}{c}-0.028 \\
1.38\end{array}$ & $\begin{array}{l}-1.320 * * \\
2.16\end{array}$ & $\begin{array}{l}-1.505^{* *} \\
2.36\end{array}$ \\
\hline LEARNERS & $\begin{array}{c}-2.788 \\
0.85\end{array}$ & $\begin{array}{c}-130.988^{*} \\
3.51\end{array}$ & $\begin{array}{c}-116.064^{* * *} \\
2.03\end{array}$ \\
\hline $\begin{array}{l}\text { CONSTANT } \\
R^{2}\end{array}$ & $\begin{array}{l}-6.227^{*} \\
3.79 \\
0.79\end{array}$ & $\begin{array}{c}438.704^{*} \\
6.68\end{array}$ & $\begin{array}{c}312.160^{*} \\
4.16\end{array}$ \\
\hline $\begin{array}{l}N \\
F\end{array}$ & $\begin{array}{l}57 \\
21.43\end{array}$ & 57 & 57 \\
\hline $\begin{array}{l}\text { MEAN DEP. } \\
\text { VARIABLE }\end{array}$ & 1.15 & 515.53 & 502.84 \\
\hline
\end{tabular}

Note: $*, * *$ and $* * *$ significant (two-tailed test) at 1, 5 and $10 \%$ levels, respectively

Ethnicity was excluded from the second-stage education outcome equations because studies have suggested that English fluency is more important than ethnicity in explaining educational outcomes. ${ }^{17}$ High correlation between fluency and ethnicity would likely lead to multicollinearity and therefore inflated SEs as well.

\section{Estimation Results}

Four sets of estimations are discussed with each containing a different measurement of private school enrollment. Only relationships found to be statistically significant are discussed. Table 2 displays results

${ }^{16}$ See, for example, Hamilton and Macauley (1991) and Schmidt (1992).

${ }^{17}$ See, for example, Peng and Hill (1995) and Demie (2001). 
Table 5. 2SLS estimates of (total) private enrollments on public school performance estimated coefficients $(t$-statistics in parentheses)

\begin{tabular}{|c|c|c|c|}
\hline & $\mathrm{Sec} 03$ & Math03 & Verbal03 \\
\hline $\begin{array}{l}\text { Dependent } \\
\text { variable }\end{array}$ & 1st Stage & 2nd Stage & 2nd Stage \\
\hline \multirow[t]{2}{*}{ INCOME } & $0.0005 *$ & $0.004^{*}$ & $0.006^{*}$ \\
\hline & 8.40 & 2.71 & 2.81 \\
\hline \multirow[t]{2}{*}{ DENSITY } & 0.001 & $0.018^{*}$ & $0.018 * * *$ \\
\hline & 1.12 & 2.86 & 1.76 \\
\hline \multirow[t]{2}{*}{ TAKE } & $-0.158 *$ & -1.469 & -1.948 \\
\hline & 2.73 & 1.42 & 1.63 \\
\hline \multirow[t]{2}{*}{ SPEND } & 0.0001 & 0.0001 & 0.003 \\
\hline & 0.31 & 0.02 & 0.53 \\
\hline PRIVATE & & $\begin{array}{l}-5.051 * * * \\
1.74\end{array}$ & $\begin{array}{c}-10.336^{* *} \\
2.27\end{array}$ \\
\hline \multirow[t]{2}{*}{ HERF } & 0.002 & -0.007 & 0.001 \\
\hline & 1.27 & 0.05 & 0.22 \\
\hline HISPANIC & $\begin{array}{l}4.995 \\
1.12\end{array}$ & & \\
\hline ASIAN & $\begin{array}{l}16.640 * * * \\
1.66\end{array}$ & & \\
\hline AFRICAN & $\begin{array}{l}9.639 \\
1.37\end{array}$ & & \\
\hline CHARTERS & $\begin{array}{c}-0.019 \\
0.46\end{array}$ & $\begin{array}{l}-1.114 * * * \\
1.91\end{array}$ & $\begin{array}{l}-0.898 \\
-1.23\end{array}$ \\
\hline LEARNERS & $\begin{array}{c}-3.711 \\
0.44\end{array}$ & $\begin{array}{c}-123.636^{*} \\
3.03\end{array}$ & $\begin{array}{c}-110.501^{* * * *} \\
1.93\end{array}$ \\
\hline CONSTANT & $\begin{array}{l}-6.943 * * * \\
1.97\end{array}$ & $\begin{array}{c}473.681^{*} \\
11.54\end{array}$ & $\begin{array}{c}417.697^{*} \\
9.29\end{array}$ \\
\hline$R^{2}$ & 0.83 & & \\
\hline$N$ & 57 & 57 & 57 \\
\hline$F$ & 27.33 & & \\
\hline $\begin{array}{l}\text { MEAN DEP. } \\
\text { VARIABLE }\end{array}$ & 6.19 & 515.53 & 502.84 \\
\hline
\end{tabular}

Note: $* * *$ and $* * *$ significant (two-tailed test) at 1,5 and $10 \%$ levels, respectively

for Catholic school enrollments. The first-stage regression indicates that enrollments are positively influenced by income, shares of students of Asian origin and public school spending. Percentages of students in charter schools and taking SAT exams exert negative effects. Second-stage regressions are displayed separately for verbal SAT and math SAT scores. Income exerts hypothesized positive influences on all test scores. More densely populated counties are found to exhibit higher math and verbal SAT scores. Catholic school enrollments exert negative effects on all test scores thus supporting the hypothesis that areas with greater private (Catholic) school enrollment also have relatively lower public school performance. Charter enrollments and percentages of students who are English-learners exert hypothesized negative influences on both test scores.

Table 3 displays results for all religious school enrollments. The first-stage regression indicates that enrollments are positively influenced by income, population density and shares of students of African descent. Percentage of test-takers exerts a negative influence. Second-stage regressions show that income and population density exert hypothesized positive influences on both test scores. Religious school enrollments exert negative effects on both test scores thus indicating that areas with greater private (religious) school enrollment also have relatively lower public school performance. Percentages of English-learners exert negative influences on both test scores.

Table 4 displays results for secular school enrollments. The first-stage regression indicates that enrollments are positively influenced by income, public school spending and shares of students of Asian descent. Second-stage regressions show that income exerts hypothesized positive influences on both test scores, that population density exerts positive influences on math SAT scores, and public school spending positively influences verbal SAT scores. Secular school enrollments exert negative effects on verbal, but not math, test scores thus indicating that areas with greater private (secular) school enrollment also have relatively lower public school performance. Charter enrollments and percentages of students who are English-learners exert hypothesized negative influences on both test scores.

Table 5 displays results for all private school enrollments. The first-stage regression indicates that enrollments are positively influenced by income and shares of students of Asian descent and negatively related to percent of students taking tests. Secondstage regressions show that income and population density exerts positive influences on both test scores. Private school enrollments exert negative effects on both test scores thus indicating that areas with greater private school enrollment also have relatively lower public school performance. Charter enrollments exert negative influences on math SAT scores and percentages of students who are English-learners exert hypothesized negative influences on both test scores.

\section{Discussion of Test Results}

First-stage estimations of private school enrollments indicate positive influences from income thus suggesting that vouchers would elicit positive responses by parents seeking greater private school choice to the extent that tuition is subsidized. Asian enrollments in public schools positively influence enrollments of Catholic, secular and all private schools. Public school spending positively influences Catholic and 
Table 6. Summary of estimated coefficients on private school enrollments

\begin{tabular}{lccll}
\hline & Catholic & Religious & Secular & $\begin{array}{l}\text { Total } \\
\text { private }\end{array}$ \\
\hline Verbal SAT & $-10.7 *$ & $-14.8 * *$ & $-27.4 * *$ & $-10.3 * *$ \\
Math SAT & $-4.3 * * *$ & $-7.8 * * *$ & -10.3 & $-5.0 * *$ \\
\hline
\end{tabular}

Note: $* * *$ and $* * *$ significant (two-tailed test) at 1,5 and $10 \%$ levels, respectively

secular enrollments, which suggest that public spending expansion by itself would not lead to higher public school performance has reflected by higher public enrollments. Public school spending does not exert significant influences on religious or total private enrollments. Greater availability of charters, as measured by percentage of all students served by charter schools, only exerts a significant negative effect on Catholic enrollments. Second-stage estimations indicate that five factors contribute significantly to public school test scores: income (positive), population density (positive), private enrollments (negative), charter enrollments (negative) and English-fluency (negative).

Table 6 compares estimated coefficients of influences on public test scores by type of private schooling. Two general conclusions are drawn. One, effects from private enrollments on (public school) verbal SATs are roughly $50 \%$ larger than on math SATs. This difference may suggest that parents who focus on verbal skills exit public schools more often than those focused on math skills. Two, secular enrollments display largest effects on verbal public school test scores indicating perhaps that secular schools serve students with relatively high verbal test scores. The effect on verbal SAT scores is roughly larger by a factor of 2.7 when compared with all private schools together. This difference is consistent with the view that secular schools prepare students for entry into elite universities. Interestingly, the estimated coefficient of the effect of secular enrollments on public math SAT scores is not significantly different from zero, and this is the only coefficient in the table that is not statistically significant. However, it should also be noted that the effects of the other three private enrollments on math SAT scores are only significant at the $10 \%$ level thus indicating that overall effects of private enrollments on math SAT scores are not particularly strong when compared to those exerted on verbal SAT scores.

Effects of private enrollments on public test scores are quite impressive when evaluated at average SAT scores. For example, a 10\% increase in (combined) private enrollments exerts a $20 \%$ fall $-\$ 103.4$ point drop from 503 to 399.6 - in public verbal SAT test scores. A $10 \%$ increase in (combined) private enrollments exerts a $10 \%$ fall - a 50.5 point drop from 515 to 464.5 - in public math SAT test scores.

\section{Conclusion}

The evidence indicates that public school test scores are inversely related to private enrollments thus supporting the view that private enrollments partly reflect exiting from public schools due to poor academic performance. A $10 \%$ increase in private enrollments is estimated to exert a $20 \%$ fall in verbal SAT scores and a $10 \%$ fall in math test scores of public schools. The evidence therefore indicates that, after controlling for other important factors, public schools exhibit higher test scores in communities with relatively low private enrollments. The evidence also indicates that charter school enrollments are exerting negative influences on public test scores thus reinforcing the evidence from private schools that suggests that traditional public schools are perceived as inferior.

Results should be interpreted with caution. It is inappropriate to simply project these empirical results to the future because estimates are drawn from data on current enrollments that are unlikely to resemble future populations. Although more parents may choose private schooling following expanded private school choice, it remains unclear if they would exhibit similar commitments to private education and bear children with similar academic capabilities. It remains unclear what marginal effect a new batch of private enrollments would exert on test scores of public schools and it is unlikely that effects would approach those reported in this article.

It is also probably inappropriate to conclude that private school choice reform would lead to permanent further erosion of public school performance based on our empirical evidence because long-term effects on performance critically depend on how public schools react to heightened private school competition. Proponents of school choice predict changes that arise from the competitive model - i.e. exiting to private schools is a short-term phenomenon that fades as public schools improve performance. However, another scenario is that public schools somehow fail to stem student flight when, for example, public schools do not view student flight as much of a threat - financially or otherwise - to their existence, especially given low probabilities that public schools will be shut-down in the process. Private school choice reform that expands private 
enrollments to critical competitive thresholds may be required before improvements in public schools may be detected. ${ }^{18}$ Some public schools may also find it very difficult to improve performance, given that constraints imposed by school boards, teacher unions or falling peer group quality may hinder improvement efforts despite growing threats from private schools. Empirical examination of these dynamics requires a longer time period and data sets that include significant changes in private school choice such as sizable vouchers.

\section{Acknowledgements}

I am indebted to an anonymous referee for many excellent comments.

\section{References}

Alt, M. N. and Peter, K. (2003) Private Schools: A brief portrait, in The Condition of Education 2002, US Department of Education, Washington, DC.

Belfield, C. R. and Levin, H. M. (2001) The effects of competition between schools on educational outcomes: A review for the United States, Review of Educational Research, 71, 279-341.

Betts, J. R. (1995) Does school quality matter? evidence from the national longitudinal survey of youth, The review of economics and statistics, 77, 231-50.

Blair, J. P. and Staley, S. (1995) Quality competition and public schools: Further evidence, Economics of Education Review, 14, 193-208.

California Department of Education. (2007) Enrollment and Staff in California Private Schools 2003-2004, School Improvement Division, Sacramento.

Card, D. and Krueger, A. (1992) Does school quality matter: returns to education and the characteristics of public schools in the United States, Journal of Political Economy, 100, 1-40.

Coleman, J., Campbell, E., Hobson, C., McPartland, J., Mood, A., Weinfeld, F. D. and York, R. (1966) Equality of Educational Opportunity, Education and Welfare, Washington D.C.

Dee, T. S. (1998) Competition and the quality of public schools, Economics of Education Review, 17, 419-27.

Demie, F. (2001) Ethnic and gender differences in educational achievement and implications for school improvement strategies, Educational Research, 43, 91-106.
Downes, T. A. and Greenstein, S. M. (1996) Understanding the supply decisions of nonprofits: Modeling the location of private schools, Rand Journal of Economics, 27, 365-90.

Friedman, M. (1995) The role of government in education, by Milton Friedman, in From Economics and the Public Interest (Ed.) R. A. Solo, Rutger's University Press, New Brunswick.

Greene, K. V. and Kang, B.-G. (2004) The effect of public and private competition on high school outputs in New York State, Economics of Education Review, 23, 497-506.

Grogger, J. (1996b) School expenditures and post-schooling earnings: evidence from high school and beyond, The Review of Economics and Statistics, 78, 628-37.

Hamilton, B. W. and Macauley, M. K. (1991) Determinants to consequences of public-private school choice, Journal of Urban Economics, 3, 282-94.

Hanushek, E. A. (1986) The economics of schooling, Journal of Economic Literature, 24, 1141-77.

Hanushek, E. A., Rivkin, S. G. and Taylor, L. L. (1996) Aggregation and the estimated effects of school resources, The Review of Economics and Statistics, $\mathbf{7 8 ,}$ 611-27.

Hedges, L., Laine and Greenwald, R. (1994) Does money matter: A meta analysis of studies of the effects of differential school inputs on school outcomes, Education Researcher, 22, 5-14.

Hoxby, C. (2002) School choice and school productivity (or, could school choice be a tide that lifts all boats?), National Bureau of Economic Research Working Paper No. 8873, April 2002.

Hoxby, C. M. (2003) How School Choice Affects the Achievement of Public School Students, in Choice with Equity (Ed.) P. T. Hill, Hoover Institution Press, Stanford, CA, pp. 141-178.

Jepsen, C. (2002) . The role of aggregation in estimating the effects of private school competition on student achievement, Journal of Urban Economics, 42, 477-500.

Kenny, L. W. (2005) The public choice of educational choice, Public Choice, 124, 205-22.

Lankford, H. and Wyckoff, J. (1992) Primary and secondary school choice among public and religious alternatives, Economics of Education Review, 11, 317-37.

Marlow, M. L. (1997) Public education supply and student performance, Applied Economics, 29, 617-26.

Marlow, M. L. (2000) The effects of spending and school structure on public education quality, Economics of Education Review, 19, 89-106.

Martinez-Vazquez, J. S. B. A. (1985) Private schooling and the tiebout hypothesis, Public Finance Quarterly, 13, 293-318.

National Center for Education Statistics, (2002) Digest of Education Statistics, U.S. Department of Education, Washington, DC.

\footnotetext{
${ }^{18}$ A weak market share for private schools may result in competitive pressures that do not reach critical thresholds necessary for influencing behaviour of public schools. Hoxby (2003) discusses this possibility. Vouchers and tax-preferences that lower costs of private enrollments would lower price differentials between private and public schooling and likely lead to a greater competitive presence from private schools. Marlow (1997, 2000), Dee (1998), Hoxby (2002) and Greene and Kang (2004) report evidence in support of the hypothesis that various forms of competition improve public school performance. Although opposing evidence is reported in Sander (1999) and Jepsen (2002), Belfield and Levin's (2001) summary of the literature concludes that a majority of studies find that competition improves public school performance.
} 
Peng, S. S. and Hill, S. T. (1995) Understanding racial-ethnic differences in secondary school science and mathematics achievement, Diane Books Publishing Company, Darby, PA.

Sander, W. (1999) Private schools and public school achievement, Journal of Human Resources, 34, 697-709.

U. S. Department of Commerce, (2003) Statistical Abstract of the United States, Washington.

Tiebout, C. M. (1956) A pure theory of local expenditures, Journal of Political Economy, 64, 416-24.

U.S. Department of Education, (2002) National center for education statistics, Private Schools: A Brief Portrait,
(Eds) M. N. Alt and K. Peter, NCES 2002-013, Washington, DC.

U.S. Department of Education. (2003) National center for education statistics, Trends in the Use of School Choice: 1993 to 1999, (Eds) S. Bielick and C. Chapman, NCES 2003-031, Washington, DC.

West, E. G. (1990) Public education via exclusive territories, Public Finance Quarterly, 18, 371-94.

Zanzig, B. R. (1997) Measuring the impact of competition in local government education markets on the cognitive achievement of students, Economics of Education Review, 16, 431-41. 